\title{
PENERAPAN MODEL PEMBELAJARAN INKUIRI UNTUK MENINGKATKAN HASIL BELAJAR IPA
}

\author{
Ni Wayan Juniati ${ }^{1, *}$, I Wayan Widiana ${ }^{2}$ \\ 1,2Jurusan Pendidikan Guru Sekolah Dasar, Fakultas IImu Pendidikan \\ Universitas Pendidikan Ganesha \\ Singaraja, Indonesia
}

E-Mail: wayan_juniati@yahoo.co.id ${ }^{1}$, wayan_widiana@yahoo.co.id²

\begin{abstract}
Abstrak
Penelitian ini bertujuan untuk mengetahui hasil belajar IPA pada penerapan model pembelajaran Inkuiri pada siswa kelas IV SD No.5 Gulingan tahun pelajaran 2016/2017. Jenis penelitian ini adalah penelitian tindakan kelas yang dilaksanakan dalam dua siklus. Setiap siklus terdiri atas tahap perencanaan, $p$ elaksanaan tindakan, observasi/evaluasi, dan refleksi. Subjek penelitian ini adalah siswa kelas IV di SD No. 5 Gulingan, sebanyak 20 orang siswa. Data yang dikumpulkan dianalisis dengan menggunakan metode tes. Data yang didapatkan dari metode tes selanjutnya dianalisis dengan teknik deskriptif kuantitatif. Hasil penelitian ini menunjukan bahwa pembelajaran IPA dengan menggunakan model pembelajaran Inkuiri dapat meningkatkan hasil belajar siswa kelas IV di SD No. 5 Gulingan tahun pelajaran 2016/2017. Pada siklus I rata-rata hasil belajar IPA siswa sebesar $72,75 \%$ pada kategori sedang dan meningkat menjadi $80 \%$ pada siklus II yang berada pada kategori tinggi. Terjadi peningkatan sebesar $7,25 \%$. Jadi model inkuiri dapat meningkatkan hasil belajar IPA siswa kelas IV SD No. 5 Gulingan Tahun Pelajaran 2016/2017.
\end{abstract}

Kata kunci : model pembelajaran inkuiri, hasil belajar, IPA

\section{Pendahuluan}

Pendidikan merupakan pondasi utama dalam mengelola, mencetak, dan meningkatkan SDM yang berkualitas tinggi. Pendidikan dapat mengembangkan berbagai potensi yang dimiliki manusia secara optimal, yaitu mengembangkan potensi individu yang setinggi-tingginya dalam aspek fisik, intelektual, emosional, sosial dan spiritual, untuk itu pemerintah selalu berupaya untuk meningkatkan mutu pendidikan baik pada jenjang pendidikan dasar, menengah maupun jenjang pendidikan tinggi guna mempersiapkan sumber daya manusia yang berkualitas.

Pengembangan IPTEK berkaitan erat dengan penguasaan IPA. Teknologi yang dinikmati sekarang sebagian besar tercipta melalui penerapan konsep dan prinsip IPA yang diwujudkan secara teknis dalam berbagai bentuk alat dan produk teknologi. IPA mengandung tiga dimensi utama, yaitu dimensi produk, proses, dan sikap ilmiah. Dimensi produk IPA berupa fakta, konsep, prinsip, hukum, dan teori
IPA. Dimensi proses, maksudnya adalah bagaimana proses mendapatkan IPA. IPA diperoleh melalui penelitian dengan menggunakan langkah-langkah tertentu yang disebut metode ilmiah. Dimensi proses ini sangat penting dalam menunjang proses perkembangan peserta didik, anak tidak hanya memperoleh pengetahuan tetapi juga memperoleh kemampuan untuk menggali sendiri pengetahuan itu dari alam bebas. Melalui dimensi proses IPA akan dapat mengembangkan sikap ilmiah. Semiawan, dkk,(dalam Bundu, 2006) mengemukakan pentingnya penguasaan proses IPA di bangku sekolah dasar, yaitu: perkembangan ilmu pengetahuan berlangsung sangat cepat sehingga tidak mungkin lagi mengajarkan fakta dan konsep kepada siswa, (2) siswa akan lebih mudah memahami konsep yang abstrak jika belajar melalui benda-benda konkret dan langsung melakukan sendiri, (3) penemuan ilmu pengetahuan sifat kebenarannya relatif. Suatu teori yang dianggap benar hari ini, belum tentu benar 
di masa datang jika teori tersebut tidak lagi didukung oleh fakta ilmiah, (4) dalam proses belajar mengajar pengembangan konsep tidak bisa dipisahkan dari pengembangan sikap dan nilai. Keterampilan proses akan menjadi wahana penghubung antara pengembangan konsep dan pengembangan sikap dan nilai.

Berdasarkan pendapat di atas, pentingnya penguasaan proses IPA di sekolah dasar adalah siswa lebih mudah memahami konsep yang abstrak melalui benda-benda konkret, langsung melakukan sendiri dan dalam proses belajar mengajar pengembangan konsep tidak bisa dipisahkan dari pengembangan sikap dan nilai.

Salah satu indikator untuk melihat tingkat keberhasilan pengembangan kemampuan peserta didik dalam bidang IPA adalah hasil belajar IPA siswa. Hasil belajar IPA ini nantinya akan menunjukkan tingkat penguasaan IPA dari siswa. Oleh karena pentingnya IPA, maka peningkatan hasil belajar IPA secara berkesinambungan sudah menjadi pekerjaan rumah bagi pemerintah dan pihak-pihak yang terlibat dalam bidang pendidikan.

Berbagai upaya dilakukan oleh pemerintah untuk meningkatkan kualitas pendidikan khususnya hasil belajar IPA seperti pengadaan buku-buku pelajaran, pengadaan media dan sumber belajar, peningkatan kualitas guru, pengembangan inovasi pembelajaran IPA, serta penyempurnaan kurikulum dari Kurikulum Berbasis Kompetensi (KBK) menjadi Kurikulum Tingkat Satuan Pendidikan (KTSP). Berlakunya KTSP menuntut perubahan paradigma dalam pendidikan dan pembelajaran, khususnya pada jenis dan jenjang pendidikan formal. Perubahan tersebut harus pula diikuti oleh guru yang bertanggung jawab atas penyelenggaraan pembelajaran di sekolah. Salah satu perubahan paradigma pembelajaran tersebut adalah orientasi pembelajaran berpusat pada guru (teacher centered) beralih kepembelajaran yang berpusat pada siswa (student centered). Pembelajaran yang berpusat pada siswa maksudnya yaitu siswalah yang aktif membangun pengetahuannya sendiri, sedangkan guru hanya bertugas sebagai fasilitator, motivator, dan dinamisator.

Diberlakukannya KTSP oleh pemerintah menghendaki suatu pembelajaran yang pada dasarnya tidak hanya mempelajari tentang konsep, teori, dan fakta tetapi juga aplikasi dalam kehidupan sehari-hari. Dengan demikian materi pembelajaran tidak hanya tersusun atas hal-hal sederhana yang bersifat hafalan dan pemahaman, tetapi juga tersusun atas materi yang kompleks yang memerlukan aplikasi, analisis, dan sintesis. Untuk itu, guru harus bijaksana dalam menentukan suatu model yang dapat menciptakan situasi dan kondisi kelas yang kondusif agar proses pembelajaran dapat berlangsung sesuai dengan tujuan yang diharapkan.

Berdasarkan refleksi diri, maka ada beberapa permasalahan sebagai penyebab rendahnya hasil belajar IPA siswa, yaitu: 1) masih menggunakan model pembelajaran konvensional dalam membelajarkan siswa. Hal ini akan mengakibatkan siswa menjadi pasif karena pembelajaran didominasi oleh guru. Pembelajaran seperti ini akan membuat siswa tidak termotivasi untuk mengikuti proses pembelajaran karena mereka beranggapan bahwa materi yang diajarkan terlalu abstrak dan sulit untuk dimengerti, 2) dalam mengajar hanya menggunakan satu sumber belajar. Hal tersebut akan mengakibatkan kemampuan siswa menjadi terbatas sehingga akan berdampak pada rendahnya hasil belajar IPA siswa, 3) sulit melibatkan siswa secara aktif dalam proses pembelajaran sehingga aktivitas siswa menjadi pasif, 4) sebagian besar siswa menganggap bahwa IPA adalah pelajaran menghapal, membosankan, dan kurang menantang. Hal tersebut mengindikasikan bahwa guru memperkenalkan IPA hanya sebatas dimensi produk saja, dengan mengabaikan dimensi proses dan dimensi sikap ilmiah, dan 5) siswa kurang dibiasakan bekerja dalam kelompok, sehingga terdapat kecenderungan yang pintar akan semakin pintar dan yang kurang akan semakin kehilangan kesempatan untuk mengembangkan kompetensi yang dimilikinya. Ini disebabkan karena tidak adanya sharing 
pendapat atau diskusi terhadap suatu permasalahan. Dalam pelaksanaannya, guru menjadi salah satu ujung tombak dalam mengeksekusi kegiatan-kegiatan yang dapat memajukan pendidikan nasional. Guru yang menjadi ujung tombak pelaksanaan pendidikan nasional haruslah professional. Guru professional (dalam Kurniasih, 2015) adalah semua orang yang mempunyai kewenangan serta bertanggung jawab tentang pendidikan anak didiknya, baik secara individual atau klasikal, di sekolah atau di luar sekolah.

Hasil belajar siswa yang tinggi dalam proses pembelajaran diperlukan dalam setiap mata pelajaran. Hal ini dapat menjadi salah satu indikator keberhasilan dalam proses pelaksanan kegiatan pembelajaran. Hal ini juga diperlukan dalam kegiatan pembelajaran IImu Pengetahuan Alam. IImu PengetahuanAlam sebagai sebuah disilplin ilmu dan penerapannya dalam masyarakat membuat pendidikan IPA menjadi penting. Dalam kegiatan pembelajarannya peserta didik diberikan kesempatan untuk berlatih keterampilanketerampilan IPA, sebab diharapkan mereka dapat berpikir dan memiliki sikap ilmiah. Paolo dan Marten (dalam Carin, 1993) menegaskan di dalam IPA tercakup juga coba-coba dan melakukan kesalahan, gagal, dan mencoba lagi. Ilmu Pengetahuan Alam tidak menyediakan semua jawaban untuk masalah yang diajukan sehingga guru dan siswa harus tetap bersikap skeptis sehingga selalu siap memodifikasi model-model yang kita punyai tentang alam ini sejalan dengan penemuan-penemuan yang kita dapatkan.

Berdasarkan observasi yang dilaksanakan pada tanggal 24 Agustus 2016 dengan rata-rata hasil ulangan harian mata pelajaran IPA $50 \%$ yang belum memenuhi KKM yang ditentukan yaitu 73 , hal ini dapat dilihat sebanyak 10 siswa dari 20 siswa berada di bawah KKM. Untuk mengatasi permasalahan tersebut, maka perlu dicarikan solusi agar pembelajaran IPA yang dilaksanakan menjadi lebih bermakna sehingga dapat memberikan pengaruh positif terhadap peningkatan hasil belajar IPA siswa di SD No. 5 Gulingan. Salah satu solusi untuk mengatasi permasalahan tersebut, yaitu dengan menerapkan salah satu model pembelajaran yang mampu memberikan pengalaman belajar yang melibatkan proses mental dan fisik melalui interaksi antara siswa dengan guru, siswa dengan siswa, lingkungan, dan sumber belajar lainnya dalam situasi yang menyenangkan bagi siswa.

Ketika observasi dilakukan saat guru mengajar, ditemukan bahwa dalam proses pembelajaran guru lebih banyak memberikan informasi dengan cara yang kurang menarik, serta kurangnya peran serta media yang digunakan. Kegiatan pembelajaran yang dilakukan hanya sebatas penjelasan materi, pemberian contoh dan soal-soal sebagai latihannya. Dengan proses pembelajaran seperti itu, mengakibatkan siswa menjadi kurang aktif dan tidak ada aktivitas siswa yang sangat berperan. Hal tersebut terjadi sering juga ditemukan dilapangan bahwa guru menguasai materi pelajaran dengan baik tetapi tidak dapat melaksanakan kegiatan pembelajaran dengan baik, misalnya seorang guru matematika belum tentu pintar mengajar matematika. Karena terlalu mengikuti alur materi tanpa menyadari bagaimana kemampuan siswa maka proses pembelajaran tidak akan berhasil. Ada juga guru yang pintar matematika namun dalam pembelajaran menggunakan metode yang salah, hal ini juga tidak akan berhasil meningkatkan pemahaman siswa tentang materi.

Untuk menghindari proses pembelajaran seperti itu maka dilaksanakan model pembelajaran inkuiri, untuk memperbaharui proses belajar siswa. Penggunaan model inkuiri akan menciptakan kegiatan pembelajaran yang lebih menyenangkan dan akhirnya berpengaruh pada pemahaman konsep yang ditemukan. Pada prinsipnya tujuan pengajaran inkuiri membantu siswa bagaimana merumuskan pertanyaan, mencari jawaban atau pemecahan untuk memuaskan keingintahuannya dan untuk membantu teori dan gagasannya tentang dunia. Lebih jauh lagi dikatakan bahwa pembelajaran inkuiri bertujuan untuk mengembangkan tingkat berpikir dan juga keterampilan berpikir kritis. Penerapan model ini sangat penting diterapkan dalam upaya meningkatkan mutu pendidikan. 
Berdasarkan penelitian yang dilakukan oleh I Ketut Tunas Arnawa (2007), diketahui bahwa penerapan model pembelajaran inkuiri dapat meningkatkan hasil belajar Matematika. Hal ini ditunjukkan dari hasil penelitian yang dilakukan di kelas III Tianyar, persentase ketuntasan pada siklus I sebesar $54,6 \%$ dan pada siklus II sebesar 73,8\%. Terjadinya peningkatan sebesar $19,2 \%$. $\mathrm{Ni}$ Nyoman Sri Astuti (2010) yang dilakukan di SD Seraya Barat terlihat persentase ketuntasan pada siklus I sebesar $61,90 \%$ dan pada siklus II sebesar 90,48 , terjadi peningkatan sebesar 28,58\%. Wawan Handari ( 2008 ) telah mengadakan penelitian dimana menerapkan Model Pembelajaran Inkuiri dalam pembelajaran IPA untuk meningkatkan hasil belajar IPA pokok bahasan Cahaya pada siswa kelas V SD No. 7 Serang Tahun Ajaran 2008/2009. Hasil penelitian menyimpulkan bahwa penerapan model pembelajaran Inkuiri ternyata dapat meningkatkan hasil belajar IPA dalam pokok bahasan Cahaya pada siswa kelas V SD N0.7 Serang Tahun Ajaran 2008/2009. Pada siklus Irata-rata (M) sebesar 69 , daya serap sebesar $69 \%$ dan ketuntasan belajar sebesar $60 \%$. Sedangkan pada siklus II rata-rata (M) sebesar 80 , daya serap sebesar $83 \%$ dan ketuntasan belajar sebesar $84 \%$ sehingga melebihi target yang ditetapkan. Dari ke tiga penelitian yang dilakukan maka dapat disimpulkan bahwa penerapan model pembelajaran inkuiri dapat meningkatkan hasil belajar IPA. Beracuan pada uraian di atas, maka dipandang perlu dilaksanakan penelitian yang berjudul "Penerapan Model Pembelajaran Inkuiri untuk Meningkatkan Hasil Belajar IPA Siswa Kelas IV SD No. 5 Gulingan Tahun Pelajaran 2016/2017".

Berdasarkan latar belakang masalah, maka dapat dirumuskan permasalahan, yaitu apakah Penerapkan Model Pembelajaran Inkuiri dapat meningkatkan hasil belajar IPA siswa kelas IV SD No 5 Gulingan Tahun Pelajaran 2016/2017 ? Maka tujuan penelitian ini adalah untuk mengetahui peningkatan hasil belajar IPA siswa kelas IV SD No 5 GulinganTahun Pelajaran
2016/2017 setelah penerapan model pembelajaran Inkuiri.

Ada dua jenis manfaat yang dapat diperoleh dari hasil penelitian ini, yaitu manfaat teoritis dan manfaat praktis. Hasil penelitian ini dapat dijadikan sebagai salah satu bahan referensi berguna bagi pengembangan ilmu pendidikan, khususnya pada pengembangan hasil belajar IPA siswa. (1) Bagi Siswa Sekolah Dasar No. 5 Gulingan, Hasil Penelitian ini dapat membantu siswa untuk memperoleh pengalaman belajar lebih bermakna sehingga siswa lebih banyak membelajarkan diri serta diharapkan dapat meningkatkan hasil belajar IPA. (2) Bagi Guru Sekolah Dasar No. 5 Gulingan Hasil penelitian ini dapat digunakan sebagai sumber informasi serta masukan (input) dalam mengembangkan alternatif pembelajaran yang dapat meningkatkan hasil belajar IPA Sekolah Dasar No. 5 Gulingan serta dapat memperoleh wawasan tentang pembelajaran dengan menerapkan model pembelajaran Inkuiri (3) Bagi Sekolah Dasar No. 5 Gulingan, Hasil penelitian ini dapat menjadi informasi berharga bagi kepala sekolah untuk mengambil suatu kebijakan yang paling tepat dalam kaitannya dengan upaya pemilihan model yang efektif dan efisien diterapkan di sekolah. (4) Peneliti Lain, Hasil penelitian dapat memberikan informasi berharga bagi para peneliti dibidang pendidikan (model pembelajaran), untuk meneliti aspek atau variabel lain yang diduga memiliki kontribusi terhadap konsep-konsep dan teori-teori tentang model pembelajaran.

\section{Metode}

Penelitian yang dilaksanakan adalah penelitian tindakan kelas (Classroom Action Reseach). Menurut Kunandar (2011), "Penelitian tindakan kelas dapat didefinisikan sebagai suatu penelitian tindakan (action research) yang dilakukan oleh guru yang sekaligus sebagai peneliti di kelasnya atau bersama-sama dengan orang lain (kolaborasi) dengan jalan merancang, melaksanakan dan merefleksi tindakan secara kolaboratif dan partisipatif yang bertujuan untuk memperbaiki atau meningkatkan mutu (kualitas) proses 
pembelajaran di kelasnya melalui suatu tindakan (treatment) tertentu dalam suatu siklus." Menurut Agung (2014), "PTK sebagai suatu bentuk penelitian yang bersifat reflektif dengan melakukan tindakan tindakan tertentu agar dapat memperbaiki dan atau meningkatkan praktek praktek pembelajaran di kelas secara lebih professional".

Ada empat tahapan pada satu siklus penelitian. Keempat tahapan tersebut terdiri dari: perencanaan, tindakan, observasi/evaluasi, dan refleksi. Dapat disimpulkan PTK adalah tindakan yang secara langsung untuk memperbaiki masalah yang dihadapi di dalam kelas sehingga masalah di dalam kelas menjadi kondusif sehingga hasil belajar siswa menjadi meningkat.

Penelitian tindakan kelas ini dilaksanakan di SD No.5 Gulingan Kabupaten Badung, pada semester 1 tahun ajaran 2016/2017. Adapun subjek penelitian adalah siswa kelas IV Tahun Pelajaran 2016/2017, dengan jumlah siswa 20 orang dimana terdapat 13 orang siswa laki-laki dan 7 orang siswa perempuan. Objek penelitian tindakan kelas ini adalah hasil belajar IImu Pengetahuan Alam (IPA) pada siswa kelas IV semester 1 SD Negeri 5 Gulingan tahun pelajaran 2016/2017.

Dalam kegiatan PTK ini, peneliti bekerjasama dengan kepala sekolah dalam membuat suatu kesepakatan baik dalam menentukan jadwal, pendekatan

pembelajaran yang digunakan dalam penelitian.

Sesuai dengan prosedur Penelitian Tindakan Kelas (PTK), penelitian ini dilakukan dalam beberapa siklus. Setiap siklus terdiri dari 4 tahapan yaitu terdiri dari: pertama Perencanaan, langkah yang dilakukan oleh guru ketika akan memulai tindakan memperbaiki, meningkatkan atau perubahan perilaku dan sikap sebagai solusi. Kedua Pelaksanaan, implementasi dari perencanaan yang telah dipersiapkan untuk dilakukan oleh guru sebagai upaya meningkatkan perubahan yang diinginkan. Ketiga Pengamatan, proses mencermati jalannya pelaksanaan tindakan atau mengamati hasil atau dampak dari perlakuan atau tindakan yang diberikan. Keempat Refleksi, peneliti mengkaji, melihat dan mempertimbangkan hasil atau dampak dari tindakan dari berbagai kriteria. Berikut ini disajikan langkah masing-masing tahapan.

\section{Hasil Dan Pembahasan}

Sesuai dengan permasalahan
yang diungkapkan pada bagian
pendahuluan, dilaksanakan tindakan
dengan menerapkan model pembelajaran
linkuri pada pembelajaran IPA siswa kelas
IV SD No. 5 Gulingan tahun ajaran
$2016 / 2017$ dengan jumlah subjek
sebanyak 20 orang siswa. Data yang
dikumpulkan dalam penelitian ini adalah
data mengenai hasil belajar IPA. Rincian
mengenai data tersebut dapat dijelaskan
sebagai berikut.

Tabel 1. Deskripsi Kondisi Awal Siswa

\begin{tabular}{cccc}
\hline No & Kode Siswa & Nilai & Ketuntasan \\
\hline 1 & 001 & 65 & Tidak Tuntas \\
2 & 002 & 70 & Tidak Tuntas \\
3 & 003 & 73 & Tuntas \\
4 & 004 & 73 & Tuntas \\
5 & 005 & 70 & Tidak Tuntas \\
\hline 6 & 006 & 73 & Tuntas \\
7 & 007 & 70 & Tidak Tuntas \\
8 & 008 & 73 & Tuntas \\
9 & 009 & 70 & Tidak Tuntas \\
10 & 010 & 65 & Tidak Tuntas \\
11 & 011 & 65 & Tidak tuntas
\end{tabular}




\begin{tabular}{cccc}
\hline No & Kode Siswa & Nilai & Ketuntasan \\
\hline 12 & 012 & 73 & Tuntas \\
13 & 013 & 73 & Tuntas \\
14 & 014 & 73 & Tuntas \\
15 & 015 & 70 & Tidak Tuntas \\
16 & 016 & 65 & Tidak Tuntas \\
17 & 017 & 55 & Tidak tuntas \\
18 & 018 & 65 & Tidak Tuntas \\
19 & 019 & 50 & Tidak Tuntas \\
20 & 020 & 50 & Tidak Tuntas \\
\hline
\end{tabular}

Pelaksanaan Tindakan Siklus I dilaksanakan dalam empat kali proses pembelajaran dan satu kali pertemuan, terdiri dari tiga kali pertemuan pertemuan untuk evaluasi.

Tabel 2. Jadwal Pelaksanaan Penelitian Siklus I

\begin{tabular}{ccc}
\hline No & Hari/Tanggal & Kegiatan \\
\hline 1 & Selasa, 18 Oktober 2016 & RPP 1 \\
2 & Kamis, 20 Oktober 2016 2 RPP 2 \\
2 & Selasa, 25 Oktober 2016 & RPP 3 \\
2 & Kamis, 27 Oktober 2016 & Tes Hasil Belajar Siklus I \\
\hline
\end{tabular}

Pelaksanaan pembelajaran disesuaikan dengan RPP yang telah disusun pada tahap perencanaan dengan materi pelajaran. Secara singkat urutan proses pembelajaran yang dilakukan pada setiap pertemuan siklus I sebagai berikut.

Pertama Membagi siswa dalam bentuk kelompok. Kedua Menyajikan materi pelajaran. Ketiga Diberikan waktu untuk berdiskusi Dalam diskusi kelompok, guru mengarahkan kelompok. Keempat Salah satu dari anggota kelompok mempresentasikan hasil kerja kelompoknya. Kelima Guru memberikan pertanyaan Siswa diberikan untuk memberikan tanggapan. Keenam Penguatan dan kesimpulan secara bersama-sama Melakukan pengamatan atau observasi.

Tabel 3. Data Tentang Hasil Belajar IPA Siswa

\begin{tabular}{ccccc}
\hline No & Kode Siswa & Skor & Nilai & Ketuntasan \\
\hline 1 & 001 & 15 & 75 & Tuntas \\
2 & 002 & 16 & 80 & Tuntas \\
3 & 003 & 15 & 75 & Tuntas \\
4 & 004 & 15 & 75 & Tuntas
\end{tabular}
setiap pertemuan, kemudian pada pertemuan keempat dilakukan tes untuk mengetahui hasil belajar IPA pada siklus Data Hasil Belajar IPA Siswa

Hasil belajar IPA siswa dinilai dengan menggunakan tes hasil belajar berupa soal obyektif. Berjumlah 20 soal terkait materi pembelajaran yang telah diuji dengan menggunakan rumus yang telah dipaparkan pada Bab III. Rumus yang digunakan sebagai berikut:

$$
\text { Nilai }=\frac{\text { Skor } \text { y ang di peroleh }}{\text { Skor Maksimal }} \times 100
$$

Data hasil belajar IPA siswa akan di sajikan dalam tabel 3 dibawah ini. 


\begin{tabular}{ccccc}
\hline No & Kode Siswa & Skor & Nilai & Ketuntasan \\
\hline 5 & 005 & 15 & 75 & Tuntas \\
6 & 006 & 15 & 75 & Tuntas \\
7 & 007 & 15 & 75 & Tuntas \\
8 & 008 & 15 & 75 & Tuntas \\
9 & 009 & 14 & 70 & Tidak Tuntas \\
10 & 010 & 15 & 70 & Tidak Tuntas \\
11 & 011 & 13 & 65 & Tidak Tuntas \\
12 & 012 & 15 & 75 & Tuntas \\
13 & 013 & 16 & 80 & Tuntas \\
14 & 014 & 16 & 80 & Tuntas \\
15 & 015 & 15 & 75 & Tuntas \\
16 & 016 & 15 & 75 & Tuntas \\
17 & 017 & 15 & 75 & Tuntas \\
18 & 018 & 13 & 65 & Tidak Tuntas \\
19 & 019 & 12 & 60 & Tidak Tuntas \\
20 & 020 & 14 & 60 & Tidak Tuntas \\
& Jumlah & & 1.455 & \\
\hline
\end{tabular}

Berikut proses penghitungan tentang hasil belajar siswa.

1. Menghitung rata-rata hasil belajar IPA Rata-rata hasil belajar IPA siswa dianalisis dengan rumus sebagai berikut.

$$
\begin{aligned}
M & =\frac{\sum x}{N} \\
& =\frac{1.455}{20} \\
& =72.75 \%
\end{aligned}
$$

2. Menentukan persentase rata-rata hasil belajar IPA

Persentase rata-rata hasil belajar dianalisis dengan rumus sebagai berikut.

$$
\begin{aligned}
M(\%) & =\left(\frac{M}{\operatorname{SMI}}\right) \times 100 \% \\
= & \left(\frac{72,75}{100}\right) \times 100 \% \\
& =72,75 \%
\end{aligned}
$$

3. Menghitung ketuntasan belajar siswa digunakan rumus sebagai berikut.

$$
\begin{aligned}
(K B) & =\frac{n \geq 70}{N} \times 100 \% \\
& =\frac{14}{20} \times 100 \% \\
& =70 \%
\end{aligned}
$$

Berdasarkan analisis data hasil belajar IPA siswa, diperoleh persentase rata-rata hasil belajar pada siklus I sebesar $72,75 \%$. Setelah dikonversikan pada kriteria hasil belajar IPA ternyata berada pada rentang 65\%-79\% termasuk kriteria hasil belajar sedang. Ketuntasan belajar siswa hanya mencapai $70 \%$. Dari 20 orang siswa hanya 14 orang siswa yang tuntas dan 6 orang siswa belum tuntas atau belum mencapai nilai sesuai dengan KKM yang ditetapkan yaitu 73 untuk pelajaran IPA.

\section{Refleksi Siklus I}

Proses pembelajaran pada siklus I berlangsung cukup baik. Persentase ratarata hasil belajar yang dicapai siswa pada siklus I berada pada kriteria sedang dengan ketuntasan belajar hanya mencapai $70 \%$. Hal ini menunjukkan masih terdapat $30 \%$ dari jumlah seluruh siswa yang memperoleh nilai di bawah KKM yang ditentukan. Walaupun sudah mengalami peningkatan, namun hasil yang diperoleh belum mencapai indikator keberhasilan yang ditetapkan dalam penelitian ini. Sehingga masih diperlukan adanya perbaikan pada proses pembelajaran untuk siklus ke II.

Deskripsi Hasil Penelitian Siklus II Pelaksanaan siklus II mengacu pada hasil refleksi siklus I untuk memperbaiki proses 
pembelajaran dengan model pembelajaran inkuiri. Siklus II tetap melalui tahap perencanaan, pelaksanaan, dan refleksi.

Berdasarkan refleksi siklus I dilakukan perencanaan tindakan sebagai berikut. 1) Membuat rencana pelaksanaan pembelajaran inkuiri 2) Membuat lembar kerja siswa. 3) Membuat instrument yang digunakan dalam siklus PTK. 3) Menyusun alat evaluasi pembelajaran. 4)
Menyiapkan soal-soal tes hasil belajar yang telah diujicobakan.

\section{Pelaksanaan Tindakan}

Siklus II dilaksanakan dalam empat kali pertemuan, terdiri dari tiga kali pertemuan proses pembelajaran dan satu kali pertemuan evaluasi. Berikut ini disajikan jadwal pelaksanaan tindakan siklus II.

Tabel 4. Jadwal Pelaksanaan Penelitian Siklus II

\begin{tabular}{ccc}
\hline No & Hari/Tanggal & Kegiatan \\
\hline 1 & Selasa, 1 November 2016 2016 & RPP 1 \\
2 & Kamis, 3 November 2016 2016 & RPP 2 \\
2 & Selasa, 8 November 2016 3 \\
2 & Kamis, 10 November 2016 & Tes Hasil Belajar Siklus II \\
\hline
\end{tabular}

Pelaksanaan pembelajaran dalam setiap pertemuan diupayakan adanya inovasi dan perbaikan berdasarkan kendala yang dihadapi pada siklus I, sehingga proses pembelajaran dapat berjalan lebih optimal dan membantu siswa dapat mencapai hasil belajar yang lebih baik.

Untuk mengetahui hasil belajar siswa dilakukan evaluasi dengan memberikan tes obyektif terkait materi pembelajaran. Data tentang hasil belajar yang diperoleh siswa setelah diberikan tes disajikan pada tabel berikut.

Tabel 5. Data Tentang Hasil Belajar IPA Siswa

\begin{tabular}{ccccc}
\hline No & Kode Siswa & Skor & Nilai & Ketuntasan \\
\hline$(1)$ & $(2)$ & $(3)$ & $(4)$ & $(5)$ \\
1 & 001 & 16 & 80 & Tuntas \\
2 & 002 & 17 & 90 & Tuntas \\
3 & 003 & 16 & 85 & Tuntas \\
4 & 004 & 15 & 75 & Tuntas \\
5 & 005 & 16 & 85 & Tuntas \\
6 & 006 & 16 & 80 & Tuntas \\
7 & 007 & 16 & 80 & Tuntas \\
8 & 008 & 16 & 85 & Tuntas \\
9 & 009 & 15 & 73 & Tuntas \\
10 & 010 & 16 & 85 & Tuntas \\
11 & 011 & 15 & 73 & Tuntas \\
12 & 012 & 16 & 80 & Tuntas \\
13 & 013 & 17 & 85 & Tuntas \\
14 & 014 & 19 & 95 & Tuntas \\
15 & 015 & 16 & 80 & Tuntas
\end{tabular}




\begin{tabular}{|c|c|c|c|c|}
\hline No & Kode Siswa & Skor & Nilai & Ketuntasan \\
\hline 16 & 016 & 15 & 74 & Tuntas \\
\hline 17 & 017 & 16 & 80 & Tuntas \\
\hline 18 & 018 & 14 & 70 & Tidak Tuntas \\
\hline 19 & 019 & 14 & 70 & Tidak Tuntas \\
\hline 20 & $\begin{array}{l}020 \\
\text { Jumlah }\end{array}$ & 15 & $\begin{array}{c}75 \\
1.600\end{array}$ & Tuntas \\
\hline & Rata-rata & & $80 \%$ & \\
\hline
\end{tabular}

Berikut proses penghitungan tentang hasil belajar siswa. Data diatas selanjutnya dianalisis sebagai berikut.

1. Menghitung rata-rata hasil belajar IPA Rata-rata hasil belajar IPA siswa dianalisis dengan rumus sebagai berikut.

$$
\begin{aligned}
M & =\frac{\sum X}{N} \\
& =\frac{1.600}{20} \\
& =80 \%
\end{aligned}
$$

2. Menentukan Persentase rata-rata hasil belajar IPA

Persentase rata-rata hasil belajar dianalisis dengan rumus sebagai berikut.

$$
\begin{aligned}
\mathbf{M}(\%) & =\left(\frac{M}{\operatorname{SMI}}\right) \times 100 \% \\
& =\left(\frac{80}{100}\right) \times 100 \% \\
=80 \% &
\end{aligned}
$$

3. Menghitung ketuntasan belajar siswa digunakan rumus sebagai berikut.

$$
\begin{aligned}
(K B) & =\frac{n \geq 75}{N} \times 100 \% \\
& =\frac{18}{20} \times 100 \% \\
& =90 \%
\end{aligned}
$$

Berdasarkan hasil analisis data pada siklus II diperoleh nilai rata-rata hasil belajar IPA siswa kelas IV SD No. 5 Gulingan mencapai 80 dengan persentase $80 \%$. Ketuntasan belajar siswa mencapai $90 \%$. Dari 20 siswa sebanyak 18 siswa yang sudah tuntas dan sebanyak 2 siswa atau $10 \%$ siswa yang belum tuntas.

Jika dibandingkan dengan indikator keberhasilan yang telah ditetapkan dalam penelitian ini, maka persentase rata-rata hasil belajar dan ketuntasan belajar telah mencapai indikator keberhasilan yang ditentukan.

\section{Refleksi Siklus II}

Pelaksanaan tindakan pada siklus II merupakan pengoptimalan dan antisipasi kendala yang muncul pada siklus I. Pada siklus II terjadi peningkatan persentase rata-rata hasil belajar IPA siswa kelas IV SD No. 5 Gulingan sebesar $80 \%$ dengan kriteria tinggi dan ketuntasan belajar siswa sebesar $90 \%$. Hasil yang diperoleh siswa telah memenuhi target yang ditentukan sehingga dalam penelitian ini pelaksanaan tindakan sudah cukup dilakukan dalam dua siklus. Walaupun terjadi peningkatan hasil belajar pada siklus II dan sudah mencapai indikator keberhasilan yang ditetapkan dalam penelitian, bukan berarti pembelajaran tersebut sangat sempurna. Inovasi dalam pembelajaran tetap harus dilakukan.

Penerapan model pembelajaran inkuiri dalam pembelajaran banyak memberikan kesempatan bagi siswa untuk bekerja bersama kelompok memecahkan masalah untuk mencapai tujuan. Pengelompokkan siswa yang heterogen mendorong interaksi yang kritis dan saling mendukung bagi pertumbuhan dan perkembangan pengetahuan atau kognitif siswa.

Berdasarkan data hasil belajar IPA siswa pada siklus II, indikator keberhasilan yang ditetapkan dalam penelitian ini sudah terpenuhi. Dengan mempertimbangkan hasil refleksi, diputuskan tidak melakukan siklus berikutnya.

Berdasarkan penelitian yang telah dilaksanakan dalam dua siklus yang setiap siklus terdiri dari empat kali pertemuan yaitu tiga kali pertemuan tatap muka dan satu kali pengadaan tes hasil belajar menunjukkan bahwa terjadi peningkatan pada hasil belajar dan ketuntasan belajar siswa kelas IV SD No. 5 Gulingan pada pelajaran IPA. 
Penerapan model pembelajaran inkuiri mengarahkan siswa untuk membiasakan diri aktif dan berinteraksi bersama kelompoknya. Semua anggota harus turut terlibat untuk menyelesaikan permasalahan yang disampaikan karena keberhasilan kelompok menyelesaikan tugas ditunjang oleh kerjasama anggota, sehingga anggota kelompok saling membantu.

Hasil belajar siklus I mengalami peningkatan dari $72,75 \%$ menjadi $80 \%$ pada siklus II. Hasil penelitian menunjukkan bahwa terjadi peningkatan hasil belajar siswa dari kriteria "sedang" menjadi kriteria "tinggi". Ketuntasan belajar yang diperoleh pada siklus I masih belum memenuhi kriteria yang diharapkan yaitu $72,75 \%$ siswa memperoleh nilai sesuai dengan KKM yaitu 73. Data ketuntasan belajar siklus I mencapai $70 \%$ sedangkan pada siklus II menunjukkan peningkatan menjadi $90 \%$ dimana 18 siswa sudah tuntas dan memenuhi nilai sesuai KKM.

Peningkatan hasil belajar siswa terjadi karena diterapkan model inkuiri yang dapat merangsang minat dan perhatian siswa untuk belajar, sehingga siswa mampu belajar secara aktif dalam kelompok dan belajar dengan menyenangkan melalui benda-benda abstrak yang mampu dilihat oleh siswa. Ini berarti benda abstrak merupakan sarana yang dapat mempermudah siswa untuk belajar, sehingga akan menimbulkan pengertian dan ingatan yang kuat serta dapat memberikan pengalaman langsung secara aktif untuk belajar terhadap permasalahan mereka sehari-hari.

Dari uraian di atas, secara umum telah mampu menjawab rumusan masalah. Penelitian ini dapat dikatakan berhasil, karena semua kriteria yang ditetapkan telah terpenuhi. Jadi, dapat dinyatakan bahwa penerapan model pembelajaran Inkuiri dapat meningkatkan hasil belajar IPA siswa kelas IV SD No. 5 Gulingan tahun pelajaran 2016/2017

\section{Simpulan Dan Saran}

Berdasarkan hasil penelitian tindakan kelas dengan menerapkan model pembelajaran inkuiri pada pembelajaran IPA yang dilaksanakan dalam dua siklus dapat disimpulkan bahwa penerapan model pembelajaran inkuiri dapat meningkatkan hasil belajar IPA, pada materi Sifat dan Perubahan Wujud Benda pada siswa kelas IV SD No. 5 Gulingan tahun pelajaran 2016/2017. Hal ini dapat dilihat dari ketuntasan klasikal hasil belajar siswa pada siklus I mencapai rata-rata sebesar $70 \%$ dan prosentase dikatagorikan $72,75 \%$, sedangkan pada siklus II memperoleh persentase ketuntasan klasikal hasil belajar sebesar 90\% Sehingga terjadi persentase peningkatan hasil dari siklus I ke siklus II yaitu sebesar $20 \%$.

Berdasarkan temuan-temuan dalam penelitian ini, maka diajukan saransaran sebagai berikut : pertama Kepada Guru Hasil penelitian dapat digunakan sebagai salah satu alternatif dalam upaya meningkatkan hasil belajar siswa di kelaskelas yang memiliki masalah sama dengan masalah terindentifikasi oleh peneliti. Kedua Kepada Peneliti Pengalaman pada penelitian ini agar dapat dijadikan dasar dalam penyempurnaan penerapan pembelajaran kontekstual, serta mampu menggunakan metode inovatif lain agar tercapai tujuan pendidikan sesuai dengan yang diharapkan.

Kepada siswa Siswa dalam proses pembelajaran dituntut untuk selalu aktif dan mampu menggali pengetahuan sendiri, supaya proses pembelajaran menjadi bermakna.

\section{Daftar Pustaka}

Agung, A.A Gede. 2014. Metode Penelitian

Singaraja:Fakultas

Pendidikan, Pendidikan. IImu

Pendidikan Ganesha.

Arikunto, Suharsimi. 2009. "Dasar-dasar Evaluasi Pendidikan". Jakarta : PT. Rineka Cipta.

Aunurahman,Ulfah.2012. Stop Hipertensi. Yogyakarta : Familia

Ariyanti, 2011/2012. Penerapan Model Pembelajaran PKN siswa kelas $\mathrm{V}$ SD No.

3 Gulingan

Bundu, Patta.2006. Penilaian Keterampilan Proses dan Sikap Ilmiah (Dalam Pembelajaran Sains 
Sekolah Dasar). Jakarta: Depdiknas.

Brahim, S, D. dan Zain, A. 2007. Strategi Belajar Mengajar. Jakarta: Rineka Cipta

Carin, Antur A. 1993. Teacing modern science. Sixth edition. New York: merril. Publishers.

Eggen.P.d., Kauchak. 1006. Strqategies of Teachers. New Jersey: PrenticeHall Inc Enflewood Cliffs.

Febriyani, 2014. Penerapan Model Pembelajaran Inkuiri untuk meningkatkan hasil belajar IPA siswa kelas $V$ SD No. 4 Selat Kecamatan Sukasada Tahun Pelajaran 2013/2014

Gulo, W. 2002. Metode Penelitian. Jakarta: PT. Grasindo

Imas Kurniasih S. Pd \& Berlin Sani, 2015. Ragam Pengembangan Model Pembelajaran untuk Peningkatan Profesionalitas Guru

Kunandar. (2011). Guru Profesional (implementasi Kurikulum Tingkat Satuan Pendidikan \{KTSP\}). Jakarta: PT Rajawali PersKurikulum Tingkat Satuan Pendidikan (KTSP). Jakarta: Bumi Aksara.

Nurkancana, Sunartana, 1990. Evaluasi Hasil Belajar. Surabaya: Usaha Nasional.

Nurhadi, 2003, Pembelajaran Kontekstual: Jakarta, Gramedia Widiasarana.

Prof. Dr. A.A. Gede Agung, M.Pd. 2014. Buku Ajar Metodologi Penelitian Pendidikan. Yogyakarta: Aditya Media Publishing

Setiawati , Dkk. 1993. Teknik Belajar Mengajar Dalam CBSA. Jakarta: Rineka

Suharsimi Arikunto, 2010. Dasar-dasar Evaluasi Pendidikan. Jakarta: Bumi Aksara

Thobroni, Mustofa. 2011. Belajar dan Pembelajaran: Pengembangan Wacana dan Praktik Pembelajaran dalam Pembangunan Nasional. Jakarta:Ar-Ruzz Media

Trianto, 2012. Model Pembelajaran Terpadu konsep, Strategi, dan Implementasinya dalam Kurikulum KTSP
Trianto, M.Pd. 2010. Mendesain Model Pembelajaran Inovatif-Progresif: Konsep, Landasan dan Implementasinya pada kurikulum Tingkat Satuan Pendidikan (KTSP). Jakarta: Kencana.

Usman Samatowa, 2011. Pembelajaran IPA di Sekolah Dasar. Jakarta: PT Indeks.

Winata Putra, H. Udin,S, (1992), Strategi Belajar Mengajar, Jakarta : Universitas Terbuka.

Winkel,.S. (2002). Psikologi Pengajaran. Yogyakarta: Media Abadi 